THE SCIENTIFIC METHOD 



\title{
THE SCIENTIFIC METHOD
}

\author{
An Evolution of Thinking \\ from Darwin to Dewey
}

HENRY M. COWLES 
Copyright (C) 2020 by the President and Fellows of Harvard College All rights reserved

Printed in the United States of America

\section{First printing}

Jacket design: Jill Breitbarth

Jacket art: (background) Dimitri Otis/Photographer's Choice/Getty Images; (inset) billnoll/E+/Getty images

$$
\begin{gathered}
9780674246829 \text { (EPUB) } \\
9780674246836(\mathrm{MOBI}) \\
9780674246843 \text { (PDF) }
\end{gathered}
$$

The Library of Congress has cataloged the printed edition as follows:

Names: Cowles, Henry M., 1985- author.

Title: The scientific method : an evolution of thinking from Darwin to Dewey / Henry M. Cowles.

Description: Cambridge, Massachusetts : Harvard University Press, 2020.| Includes index.

Identifiers: LCCN 2019041820 | ISBN 9780674976191 (cloth)

Subjects: LCSH: Science-Methodology-History. |

Science-Philosophy-History. | Evolution.

Classification: LCC Q174.8 .C69 2020| DDC 507.2/1—dc23

LC record available at https://lccn.loc.gov/2019041820 
For Marge, who always asked 

You must bring out of each word its practical cash-value, set it at work within the stream of your experience. It appears less as a solution, then, than as a program for more work, and more particularly as an indication of the ways in which existing realities may be changed. Theories thus become instruments, not answers to enigmas, in which we can rest. We don't lie back upon them, we move forward, and, on occasion, make nature over again by their aid.

—William James 
